\title{
Gold(I) Complexes Nuclearity in Constrained Ferrocenyl Diphosphines: Dramatic Effect in Gold-Catalyzed Enyne
} Cycloisomerization

\author{
Tuan-Anh Nguyen, ${ }^{[a]}$ Julien Roger, ${ }^{* a]}$ Houssein Nasrallah, ${ }^{[a]}$ Vincent Rampazzi, ${ }^{[a]}$ Sophie Fournier, ${ }^{[a]}$ \\ Hélène Cattey, ${ }^{[a]}$ E. Daiann Sosa Carrizo, ${ }^{[a]}$ Paul Fleurat-Lessard, ${ }^{[a]}$ Charles H. Devillers, ${ }^{[a]}$ Nadine \\ Pirio, ${ }^{[\mathrm{a}]}$ Dominique Lucas, ${ }^{[\mathrm{a}]}$ and Jean-Cyrille Hierso ${ }^{\text {[a] }}$ \\ [a] T.-A. Nguyen, Dr. J. Roger, Dr. H. Nasrallah, Dr. V. Rampazzi, S. Fournier, Dr. H.Cattey, Prof. Dr. P. Fleurat-Lessard, Dr. C. H. Devillers, Prof. Dr. N. Pirio \\ Prof. Dr. D. Lucas, Prof. Dr. J.-C.Hierso \\ Université de Bourgogne, Institut de Chimie Moléculaire de l'Université de Bourgogne, UMR-CNRS 6302 - Université Bourgogne Franche-Comté (UBFC) \\ 9, avenue Alain Savary 21078 Dijon (France). E-mail: julien.roger@u-bourgogne.fr; jean-cyrille.hierso@u-bourgogne.fr
}

\begin{abstract}
Controlling the formation of gold complexes from suited structuring polyfunctional ligands is highly attractive for all their potential applications. Herein, with constrained di-tert-butylatedbis(phosphino)ferrocene ligands, we demonstrate that the phosphino substituents $\mathrm{R}$ ( $R$ = phenyl, cyclohexyl, iso-propyl, mesityl, or furyl) induce selective formation of $\mathrm{Au}(\mathrm{l})$ halide complexes. Thus, dinuclear linear two-coordinate, but also very rare mononuclear trigonal three-coordinate and tetrahedral four-coordinate complexes were quantitatively and selectively formed upon tuning of the conditions. X-ray diffraction analysis of the resulting complexes are reported and both $\mathrm{Au}(\mathrm{I})$ chlorides and rarer iodides were synthesized. Preliminary electrochemical analyses suggested redox dissimilarities in these species. The significance of the control of structure and nuclearity in $\mathrm{Au}(\mathrm{I})$ complexes is further illustrated herein by its strong effect on the efficiency and selectivity of gold-catalysed cycloisomerization. Skeletal rearrangement reactions of 1,6-enyne up to now gave a sluggish conversion of $\mathrm{N}$-propargyl- $\mathrm{N}$-allyl toluene4-sulfonylamine with a mixture of endo and exo products in a limited conversion. Cationic linear digold(I)
\end{abstract} bis(dicyclohexylphosphino)ferrocenes outperform other catalysts in the demanding regioselective cycloisomerization of enyne sulphonamide into cyclohexadiene. Conversely, tetrahedral cationic gold complexes, used with or without $\mathrm{AgSbF}_{6}$, gave no cyclization reaction and remained unchanged. Their remarkable stability is attributed to the compact structure of the cationic complexes as attested by XRD analysis. While trigonal $\mathrm{Au}(\mathrm{I})$ complexes may achieve oxidative addition to $\mathrm{Au}(\mathrm{III})$, little is known on their potential for cyclization since the preference of $A u(I)$ for two-coordinate linear geometry mostly lead to $\mathrm{Au}$...Au dinuclear structures. The selective formation of the corresponding trigonal gold $(\mathrm{I})$ is an excellent opportunity to further investigate their catalytic potential. Herein, the well-defined trigonal mononuclear gold complexes were found incompetent for enyne cycloaddition. Accordingly, we used the twocoordinate linear electron-rich complex $\mathbf{2 b}(R=C y)$ to extend the scope of selective intramolecular cycloaddition of different 1,6enynes sulfonylamine with similar high activity and selectivity (up to $91 \%)$ to the endo products. Phenyl and 4-t-Bu-benzene sulfonates are tolerated as protecting group for the amine. Benzyl and 4fluorobenzyl groups also furnished excellent cyclization conversion (>94\%) with a high selectivity. The most challenging cycloisomerization of $\mathrm{N}$-2-methylene-propyl- $\mathrm{N}$-propargyl-toluene-4sulfonylamine was also reacted in the presence of complex $\mathbf{2 b}$. The 3-azabicyclo[4.1.0]hept-4-ene was successfully obtained as the major product and isolated.

\section{Introduction}

Gold complexes activate unsaturated carbon-carbon m-bonds as electrophiles, and gold is regarded as a mild carbophilic Lewis acid highly suitable in atom-economic cyclization processes. ${ }^{[1-3]}$ Accordingly, ligand effect in homogeneous gold catalysis became a topical subject of great interest. ${ }^{[4-6]} \mathrm{Au}$ ' species are in large majority stabilized in a two-coordinate linear geometry, which contrasts with $\mathrm{d}^{10} \mathrm{Ag}^{\prime}$ and $\mathrm{Cu}^{\prime}$ compounds for which the complexes with coordination number greater than two are more frequent. ${ }^{[7]}$ Thus, gold(I) coordination schemes with (bis)phosphino ligands mainly concerns mononuclear and dinuclear two-coordinate linear complexes (Chart 1, A and B). Comparatively, a small number of three-coordinate planar $(\mathbf{C}),{ }^{[8]}$ and four-coordinate tetrahedral (D) gold(I) halide complexes exist. ${ }^{[9,10]}$ In addition to gold-catalysed $\mathrm{C}-\mathrm{C}$ bond formation, relevant photophysical, ${ }^{[8 a, 10 a]}$ and biomedical applications ${ }^{[10 \mathrm{~d}]}$ requires a pertinent ligand control ${ }^{[9 d]}$ in forming $\mathrm{Au}^{\prime}$ well-defined complexes. Attractive closed-shell interactions between $d^{10}-d^{10}$ pairs of atoms have received increasing attention and gold dinuclear cooperative properties and reactivity have been evidenced, which encompass catalysis from dual $\sigma, \pi$-activation and gem-diaurated species. ${ }^{[6,11]}$ Advances in controlling the formation of gold complexes from suited structuring polyfunctional ligands is highly attractive for all these applications and especially digold complexes formation. 


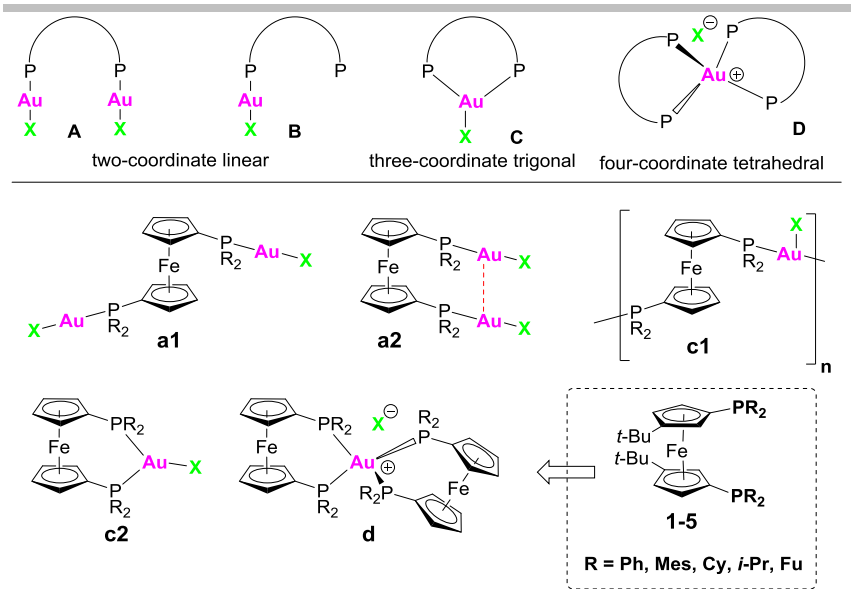

Chart 1. General coordination modes of gold(I) with diphosphines (top); Typical models for ferrocenyl diphosphines (bottom).

Structural control towards the formation of gold(I) phosphine complexes has been early on investigated using a bulky ferrocene (Fc) platform. Among other valuable properties, ferrocenyl phosphine ligands are widely functionalizable, redox active, and amenable to chirality. The pioneering studies from the groups of Hill, ${ }^{[12]}$ Laguna, ${ }^{[13]} \mathrm{Hor},{ }^{[14]}$ and others ${ }^{[8 b, 15]}$ have established that by the coordination of bis(diphenylphosphino)ferrocene ligand (dppf) to $\mathrm{Au}-\mathrm{X}$ fragments $(X=\mathrm{Cl}, \mathrm{I})$ digold $(\mathrm{I})$ halide complexes or polymers are formed. Originally, these complexes showed no closed-shell $d^{10}-d^{10}$ intramolecular aurophilic $\mathrm{Au} \cdots \mathrm{Au}$ interaction in the solid state (Chart 1, a1, $\mathbf{c 1}$ coordination modes). ${ }^{[12-15]}$

Looking for a better ligand-controlled gold complexes formation, we recently used the conformation control of di-tertbutylated-poly(phosphino)ferrocene ligands to favour the formation of $\mathrm{Au} \cdots \mathrm{Au}$ intramolecular aurophilic interactions between $\mathrm{Au}-\mathrm{Cl}$ fragments in dinuclear and polynuclear gold(I) complexes (Chart 1, a2). ${ }^{[16]}$ This conformational control, which clearly contrasts the dppf coordination to gold, was achieved by the introduction of bulky tert-butyl groups on the ferrocene platform (Chart 1, ligands 1-5).

We now report the selective synthesis and structural characterization (XRD) of $\mathrm{Au}^{\prime}$ halide complexes $(\mathrm{Cl}, \mathrm{I})$, in which each of the known structures (i. e. linear two-, trigonal three- and tetrahedral four-coordinate; Chart 1, a2, c2, d) can be formed depending on the same class of bulky ferrocenyldiphosphine ligands. Both the substituents on phosphino groups and the halide involved in the synthesis play a decisive role. The significance of the control of structure and nuclearity in $\mathrm{Au}^{\prime}$ complexes is further illustrated herein by its strong effect on the efficiency and selectivity of the elusive gold-catalysed cycloisomerization of enyne sulphonamide to its corresponding cyclohexadiene.

\section{Results and Discussion}

The ferrocenyl diphosphines rac-1-5 $\{\text { Chart 1, } t \text {-Bu-Fc[PR }]_{2}, \mathrm{R}=$ phenyl (Ph) 1, cyclohexyl (Cy) 2, iso-propyl (i-Pr) 3, mesityl
(Mes) 4, [5-methyl]-2-furyl (Fu) 5\}, ${ }^{[17]}$ where used for synthesizing mono- and dinuclear gold complexes. We investigated the synthesis and structure of dinuclear gold(I) halide complexes formed from 1-5, paying special attention to aurophilic interactions formation. The conformation control of Fc platform avoids the formation of gold polymeric chains (Chart 1 , c1). Two equiv of $\left[\mathrm{AuCl}\left(\mathrm{SMe}_{2}\right)\right]$ reacted with diphosphines 1-5 formed dinuclear gold complexes 1a to 5 a in high yield (>95\%, Scheme 1). As expected, the XRD structures of complexes 1a $(\mathrm{R}=\mathrm{Ph}), \mathbf{2 a}(\mathrm{Cy})$ and $\mathbf{5 a}(\mathrm{Fu})$ evidenced intramolecular aurophilic interaction Au1...Au2 $=3.1790(4), 3.212(4)$, and $3.2349(6) \AA$, respectively (see SI). Compound $2 \mathbf{a}(\mathrm{R}=\mathrm{Cy})$ also crystallizes in a $34 \%$ second minor isomeric form which displayed a weaker Au...Au interaction (gold-gold separation $3.457(6) \AA$ ). By comparison, the dinuclear complex formed from the meso-1 stereoisomer of $\mathbf{1}$ showed a shorter aurophilic interaction Au1...Au2 = 3.0781(6) $\AA^{[16]}$ In the solid state, complexes $\mathbf{3 a}(i-\mathrm{Pr})$ and $\mathbf{4 a}$ (Mes) adopted a conformation that precludes intramolecular aurophilic interaction, while the constraints from $t$-Bu groups mostly favoured $\mathrm{P}-\mathrm{Au}$...Au-P pairs proximity and thus aurophilic interactions. ${ }^{[16]}$ In XRD, the Au...Au distance is indicative of the presence, but is not commensurate with the strength of aurophilic interactions. Aurophilic interactions are mostly weak (comparable to $\mathrm{H}$ bonding c.a. 5-10 $\mathrm{kcal} \mathrm{mol}^{-1}$ ) and the sum of other weak interactions such as crystal packing forces may play a role in the situation for $\mathbf{3 a}$ and 4a (and partially 2a) in which no or weaker aurophilic interactions are found. Notably, a strong electron-donating effect of $i$-Pr, Mes, and Cy groups at each $\mathrm{Au}^{\prime}$ center is common to these complexes, which might possibly help offsetting M...M attractive interactions.

Gold chloride complexes are by far the most often reported, and we were intrigued by the influence of halides in the formation of $\mathrm{Au}^{\prime} \mathrm{X}$. The dinuclear complexes $\mathbf{1 b} \mathbf{b} \mathbf{4 b}$ were isolated from the reaction of two equiv of Aul with diphosphines 1-4 (Scheme 2, yields 48-99\%).
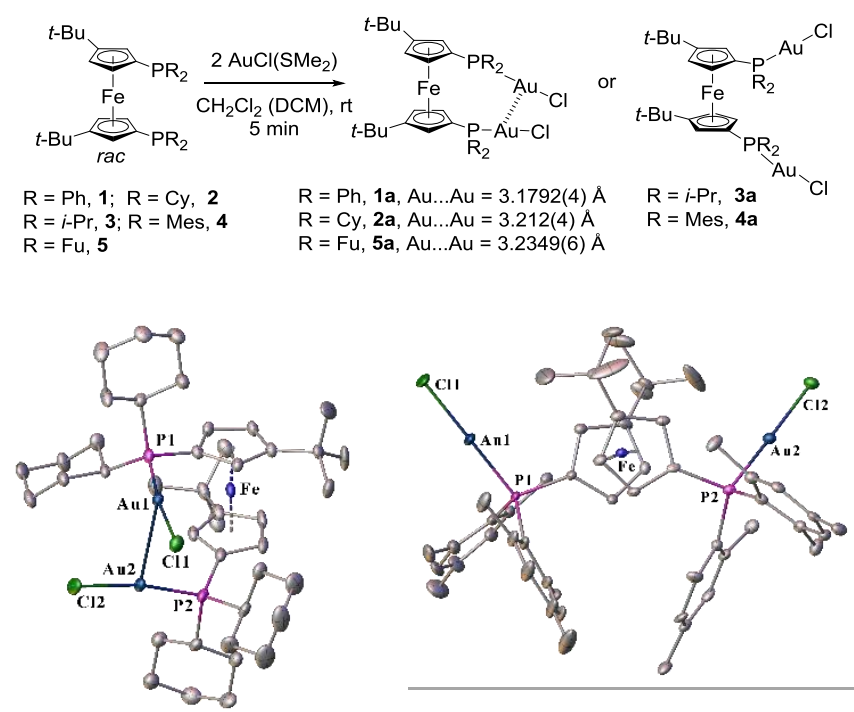

Scheme 1. Two-coordinate $\mathrm{AuCl}$ complexes 1a-5a and illustrative molecular structures for $2 \mathbf{a}$ (major isomer 66\%) and $4 \mathbf{a}\left(\mathrm{H}\right.$, and one $\mathrm{CH}_{2} \mathrm{Cl}_{2}$ for $2 \mathrm{a}$ 
omitted for clarity). Ortep of $\mathbf{1 a}$ and $\mathbf{3 a}$ are available in SI. XRD data for $\mathbf{5 a}$ were previously reported. ${ }^{[16]}$
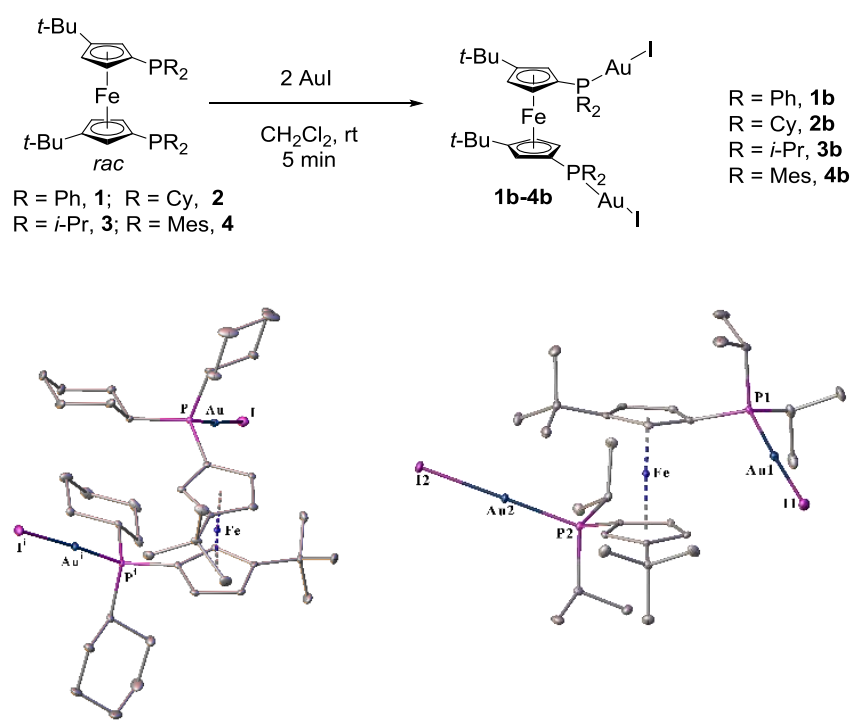

Scheme 2. Two-coordinate gold(I) iodide complexes $\mathbf{1 b}-\mathbf{4 b}$ and illustrative molecular structures for $\mathbf{2} \mathbf{b}$ and $\mathbf{3} \mathbf{b}$ ( $H$ omitted for clarity). Ortep of $\mathbf{4 b}$ is available in $\mathrm{SI}$ ). Analogue $\mathbf{5 b}$ could not be obtained in pure form.

From XRD analysis, none of the iodide complexes $\mathbf{2 b} \mathbf{b}-\mathbf{4 b}$ showed intramolecular aurophilic interaction (1) could not be crystallized). This absence in $\mathbf{2} \mathbf{b}$ was a notable difference from chloride analogue $\mathbf{2 a}$. Gold(I) complexes $\mathbf{2 a}$ and $\mathbf{2} \mathbf{b}$ were thus subjected to preliminary electrochemical analyses to possibly identify on their redox properties further unexpected halide effect. The cyclic voltammogram (CV) of the chlorinated complex $2 \mathrm{a}$ (Figure 1) exhibits a single reversible $\mathrm{Fc}$-centred oxidation at $E_{1 / 2}$ $=0.49 \mathrm{~V} v s \mathrm{Fc} / \mathrm{Fc}^{+}\left(\mathrm{O} 1 / \mathrm{R} 1\right.$ peaks, $\left.\Delta E_{\mathrm{p}}=90 \mathrm{mV}\right)$, which is similar to the analogous digold complexes $\left[\operatorname{dppf}(\mathrm{AuCl})_{2}\right.$ ] stabilized by $1,1^{\prime}$-bis(phosphino)ferrocene ligands (dppf) reported by the group of Nataro. ${ }^{[18]}$ Conversely, on the $\mathrm{CV}$ of the iodinated complex $\mathbf{2 b}$ two oxidation waves are observed. For complex $\mathbf{2 b}$ the first system centered on the Fc moiety is not fully reversible $\left(\mathrm{O} 2 / \mathrm{R} 2\right.$ peaks, $E_{\mathrm{pa}}=0.43$ and $E_{\mathrm{pc}}=0.28 \mathrm{~V} v s \mathrm{Fc} / \mathrm{Fc}^{+}, \Delta E_{\mathrm{p}}=150$ $\mathrm{mV})$, while the second redox system is reversible (O3/R3 peaks, $E_{1 / 2}=0.63 \mathrm{~V} v s \mathrm{Fc} / \mathrm{Fc}^{+}, \Delta E_{\mathrm{p}}=90 \mathrm{mV}$ ). We attributed the lack of reversibility for the first redox system in $\mathbf{2 b}$ to a fast follow-up chemical reaction consecutive to the oxidation of the Fc moiety and where the evolution product is oxidized at higher potential (peak O3). ${ }^{[19]}$

$$
t-\mathrm{Bu}
$$

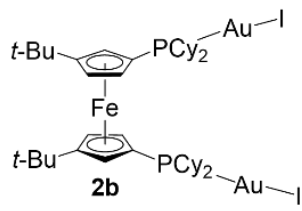

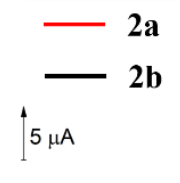

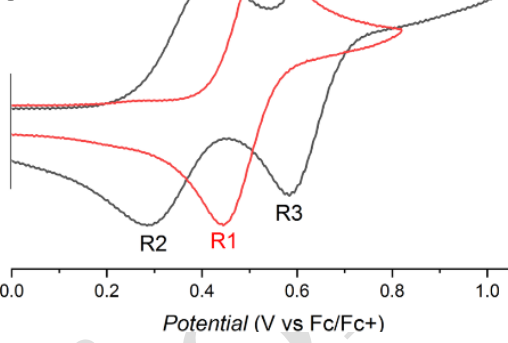

Figure 1. $\mathrm{CV}$ scans for the oxidation of $0.5 \mathrm{mM} 2 \mathrm{a}$ and $\mathbf{2 b}$ in $\mathrm{CH}_{2} \mathrm{Cl}_{2}$ at $20{ }^{\circ} \mathrm{C}$ with $0.1 \mathrm{M}(n-\mathrm{Bu})_{4} \mathrm{NPF}_{6}$ at $100 \mathrm{mV} / \mathrm{s}$.

This redox behavior, previously unseen in gold $(I)$ halide complexes constitutes -in addition to the absence of aurophilic interactions detected in the solid state- another noticeable difference between these digold(I) halides. The first oxidation potential for iodide $\mathbf{2 b}$ is significantly less positive than for chloride 2a, which is in full agreement with the electronwithdrawing effect of I vs $\mathrm{Cl}$.

We further addressed the challenging issue of selective synthesizing of mononuclear gold complexes from chelating ferrocenyl diphosphines 1-5. We were intrigued about the typical model that might be reachable (Chart $1, \mathbf{B}$, or $\mathbf{c 1}$ or $\mathbf{c 2}$ ). Are well-defined monomeric three-coordinate gold mononuclear 1,1'bis(phosphino)ferrocenes accessible, ${ }^{[8,16,20]}$ and does a selective formation of stable species could be favoured? Under our synthetic conditions, by reacting one equivalent of gold salt (either $\mathrm{AuCl}$ or $\mathrm{Aul}$ ) the diphosphines $\mathbf{4}$ and $\mathbf{5}$ unfortunately gave intractable mixtures of complexes and uncoordinated Fc. Though, we were glad to isolate from 1-3 the gold iodide mononuclear complexes 1c-3c in high yield (85 to 97\%). While the analogous gold chloride $\mathbf{2} \mathbf{d}$ could be also isolated pure in $61 \%$ yield (Scheme 3 ), the selective synthesis of gold chloride mononuclear complexes from ferrocenyldiphosphine $\mathbf{1}$ and $\mathbf{3}$ failed. Single crystals of 1c allowed a XRD analysis that ascertained a c2 coordination mode with a fairly closed angle $\mathrm{P} 1-\mathrm{Au}-\mathrm{P} 2=115.33(5)^{\circ}$. Complexes 2c (two molecules with the same conformation are present in the crystal unit, see $\mathrm{SI}$ ) and $3 c$ were characterized by $\mathrm{XRD}$, with trigonal $\mathrm{P} 1-\mathrm{Au} 1-\mathrm{P} 2=$ 117.77(5) ${ }^{\circ}$ and P3-Au2-P4 = 117.70(5) ${ }^{\circ}$, and P1-Au1-P2 = $116.75(3)^{\circ}$, respectively. In the solid state, the gold chloride $\mathbf{2 d}$ achieved a much larger trigonal angle P1-Au-P2 $=122.00(5)^{\circ}$. The formation in good yield of the four trigonal planar mononuclear $\mathbf{1 c - 3 c}$ and $\mathbf{2 d}$, demonstrates that conformationally constrained ferrocenyl diphosphines are a reliable class of ligands to selectively produce these rare chelating threecoordinate gold(I) mononuclear species. 

établissements publics, par des subventions d'agences de financement nationales ou par des fonds de l'Union européenne est publié dans un périodique paraissant au moins une fois par an, son auteur dispose, même après avoir accordé des droits exclusifs à un éditeur, du droit de mettre à disposition gratuitement dans un format ouvert, par voie numérique, sous réserve de l'accord des éventuels coauteurs, la version finale de son manuscrit acceptée pour publication, dès lors que l'éditeur met lui-même celle-ci gratuitement à disposition par voie numérique ou, à défaut, à l'expiration d'un délai courant à compter de la date de la première publication. Ce délai est au maximum de six mois pour une publication dans le domaine des sciences, de la technique et de la médecine et de douze mois dans celui des sciences humaines et sociales

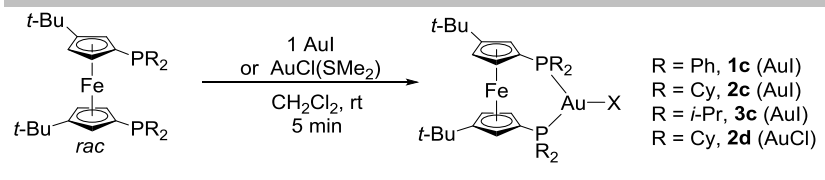

$\mathrm{R}=\mathrm{Ph}, \mathbf{1} ; \mathrm{R}=\mathrm{Cy}, \mathbf{2} ; \mathrm{R}=i-\mathrm{Pr}, \mathbf{3}$

$1 c-3 c, 2 d$
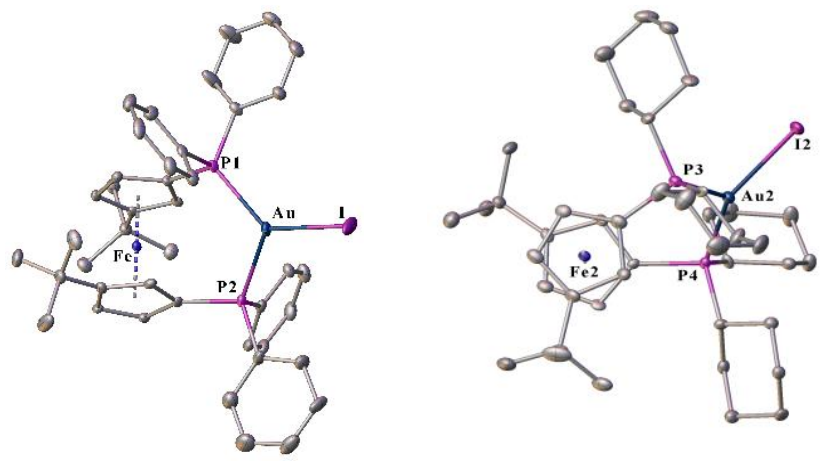

Scheme 3. Three-coordinate trigonal planar mononuclear $A u^{\prime} l$ iodide complexes 1c-3c and $\mathrm{Cl}$ analogue 2d, and illustrative molecular structures for 1c ( $\mathrm{H}$ and one $\mathrm{CH}_{2} \mathrm{Cl}_{2}$ omitted for clarity) and $2 \mathrm{c}$ (depicted here one of the two molecules of the asymetric unit). Ortep of $3 \mathrm{c}$ is available in ESI.

lodide precursor salts are preferable for the formation and stability of these monogold compounds. From ferrocenyl diphosphines 1-5 only the bis(dicyclohexyl)phosphinosubstituted 2 led to the formation of the mononuclear compounds of $\mathbf{c 2}$ type with $\mathrm{Au} \mathrm{u}^{\prime} \mathrm{Cl}$, illustrating a case of nuclearity controlled by tuning ferrocenyl diphosphine ligands. This was further supported since we eventually achieved the selective and quantitative synthesis of the trimetallic four-coordinate tetrahedral $\mathrm{Au}^{\prime}$ cationic complexes 5e,f (Figure 2, top) by using 0.5 equiv of gold halide precursors with bis(difurylphosphino)ferrocene ligand $\mathbf{5}$. Under the same conditions, 1,1'-bis(phosphino)ferrocenes 1-4 did not form the equivalent trimetallic four-coordinate complexes. The gold(I) cationisation by spontaneous halide abstraction -without the action of external additive such as sodium reagent, or silver salt- was confirmed by NMR, without notable halide effects. Complex 5e crystallized as a gold-centered regular tetrahedron $^{[10 a]}(\mathrm{dAu}-\mathrm{P}=2.3806(10)$ to $2.3874(10) \AA$, $\mathrm{P}-\mathrm{Au}-\mathrm{P}=$ $105.59(3)-114.11(4)^{\circ}$ ) in the monoclinic $P 2_{1} / c$ group (Figure 2, middle), with an intermetallic distance of $4.228(4)$ and 4.2331(8) $\AA$ between the centers in the linear $\mathrm{Fe}^{\prime \prime}$...Aul...Fe" motif. The structure seems to be stabilized by $\pi-\pi$ interactions between the four pairs of furyl rings with centroid distances ranges between 3.481(3)-3.791(3) Å. Weak bonding interactions were confirmed by analysing the Non Covalent Interactions $(\mathrm{NCl})$ in $\mathbf{5 e , f}$ (see Figure 2, bottom).
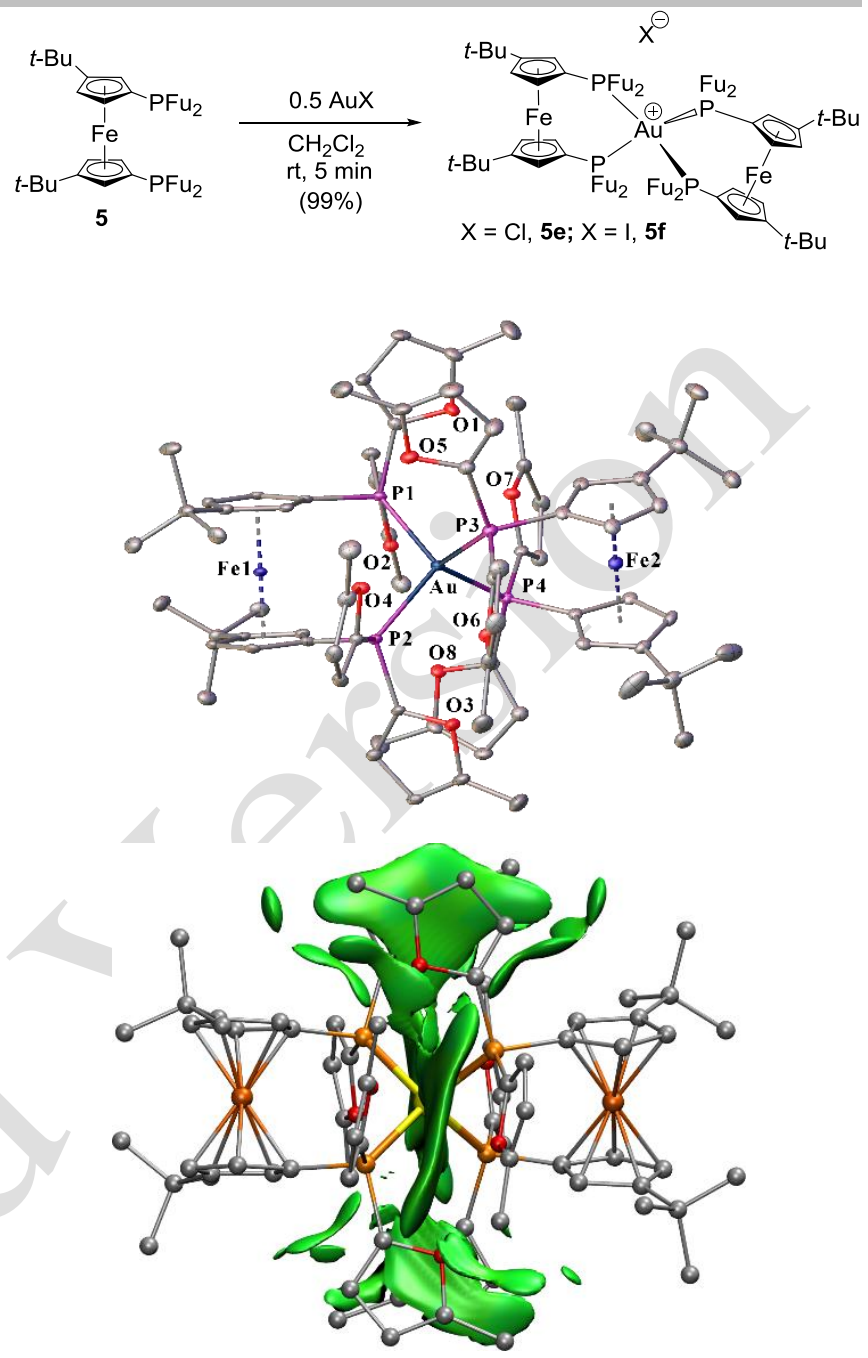

Figure 2. Synthesis and molecular structure of trimetallic 5e,f $(H$ are omitted for clarity). Non Covalent Interactions visualization (bottom right). Colors: $\mathrm{C}$ gray, $\mathrm{P}$ orange, Au yellow, O red and iron dark orange.

$\mathrm{NCl}$ visualization very clearly show that the strongest interactions are developed at the borders of the complexes between face-to-face pairs of furyl rings. This is consistent with the fact that $\pi-\pi$ interactions are favoured with electron-poor aromatics since $\pi-\pi$ repulsion is reduced. This suggests that peripheral furyl groups might be an efficient heteroaromatic for further assembling such $d^{10}$ cage tetrahedral complexes by $\pi$ stacking.

Gold salts and complexes have emerged as the most powerful catalysts for electrophilic activation of alkynes. For the activation of enynes, gold(I) complexes typically outshine activities shown by $\mathrm{Pt}(\mathrm{II})$ and other electrophilic metal salts and complexes. ${ }^{[1 \mathrm{a}]}$ Yet, the stronger Lewis acidity of gold complexes can be detrimental in terms of selectivity and because of their low tolerance to certain functional groups. The Echavarren group reported skeletal rearrangement reactions of 1,6-enynes, ${ }^{[1 \mathrm{e}]}$ with a sluggish conversion of $\mathrm{N}$-propargyl- $\mathrm{N}$-allyl toluene-4sulfonylamine 6 that gave a mixture of endo (7) and exo (8) 
products with a conversion of ca $52 \%$ and $>90 \%$ selectivity in 7 by using $\left[\mathrm{PPh}_{3} \mathrm{AuNCMe}^{+}\right]\left[\mathrm{SbF}_{6}{ }^{-}\right] .^{[21]}$ We indeed confirmed this result (Table 1, entry 1). In our preliminary screening experiments, the use of dppf and Fc analogues holding $i-\operatorname{Pr}$ or furyl groups instead of phenyl was found to be inefficient in these conditions. We investigated comparatively the activity in intramolecular cycloaddition of the 1,6-enyne 6 of $\mathrm{Au}^{\prime}$ complexes 1a-c to 5a-f, to further assess the interest in the structural control they provide.

Table 1. Intramolecular cycloaddition of 1,6-enyne 6 .

\begin{tabular}{|c|c|c|c|}
\hline & $\underbrace{=}_{\mathbf{6}} \frac{\begin{array}{c}{[\mathrm{Au}]} \\
10 \% \mathrm{AgSbF}_{6}\end{array}}{\begin{array}{c}\mathrm{CH}_{2} \mathrm{Cl}_{2}, \\
20{ }^{\circ} \mathrm{C}, 3 \mathrm{~h}\end{array}}$ & 7 & 8 \\
\hline Entry & $\begin{array}{l}\text { Catalyst } \\
\text { (2 mol\%) }\end{array}$ & $\begin{array}{l}\text { Conversion } \\
\text { in } 7+8(\%)\end{array}$ & $\begin{array}{c}\text { Selectivity } \\
\text { in } 7 \text { (\%) }\end{array}$ \\
\hline $1^{[1]]}$ & {$\left[\mathrm{PPh}_{3} \mathrm{AuNCMe}^{+}\right]\left[\mathrm{SbF}_{6}\right]$} & $50^{\mathrm{d}}$ & 91 \\
\hline 2 & $\mathrm{Aul}^{\mathrm{a}}$ & $6^{d}$ & 1 \\
\hline 3 & $\mathrm{AuCl}\left(\mathrm{SMe}_{2}\right)^{\mathrm{a}}$ & $<5^{\mathrm{a}}$ & / \\
\hline 4 & $\mathrm{AgSbF}_{6}^{\mathrm{b}, \mathrm{c}}$ & 0 & l \\
\hline 5 & (2) $\mathrm{FcPCy}_{2}{ }^{\mathrm{c}}$ & 0 & l \\
\hline 6 & $(5 \mathbf{e})\left[\mathrm{Au}-\left(\mathrm{FcPFu}_{2}\right)_{2}{ }^{+}\right]\left[\mathrm{Cl}^{-}\right]$ & 0 & 0 \\
\hline 7 & (5f) $\left[\mathrm{Au}-\left(\mathrm{FcPFu} \mathrm{u}_{2}\right)_{2}^{+}\right]\left[\mathrm{I}^{-}\right]$ & 0 & 0 \\
\hline 8 & (1c) $[$ Aul-FcPPh $]$ & 0 & 1 \\
\hline 9 & (2c) $\left[\right.$ Aul-FcPCy $\left.y_{2}\right]$ & 16 & 71 \\
\hline 10 & (2d) $\left[\mathrm{AuCl}-\mathrm{FcPCy}_{2}\right]$ & 6 & 1 \\
\hline 11 & (3c) $\left[\mathrm{Aul}-\mathrm{FcP} i-\mathrm{Pr}_{2}\right]$ & 30 & 77 \\
\hline 12 & (1a) $\left[\mathrm{Au}_{2} \mathrm{Cl}_{2}-\mathrm{FcPPh}_{2}\right]$ & 19 & 77 \\
\hline 13 & (1b) $\left[\mathrm{Au}_{2} \mathrm{I}_{2}-\mathrm{FcPPh}_{2}\right]$ & 33 & 92 \\
\hline 14 & (2a) $\left[\mathrm{Au}_{2} \mathrm{Cl}_{2}-\mathrm{FcPCy}_{2}\right]$ & 72 & 86 \\
\hline 15 & (2b) $\left[\mathrm{Au}_{2} \mathrm{l}_{2}-\mathrm{FcPCy}_{2}\right]$ & 88 & 87 \\
\hline 16 & (3a) $\left[\mathrm{Au}_{2} \mathrm{Cl}_{2}-\mathrm{FcPi}-\mathrm{Pr}_{2}\right]$ & 65 & 83 \\
\hline 17 & (3b) $\left[\mathrm{Au}_{2} \mathrm{I}_{2}-\mathrm{FcP} i-\mathrm{Pr}_{2}\right]$ & 23 & 88 \\
\hline 18 & (4a) $\left[\mathrm{Au}_{2} \mathrm{Cl}_{2}-\mathrm{FcPMes}_{2}\right]$ & 49 & 80 \\
\hline 19 & (4b) $\left[\mathrm{Au}_{2} \mathrm{l}_{2}-\mathrm{FcPMes}_{2}\right]$ & 41 & 80 \\
\hline 20 & (5a) $\left[\mathrm{Au}_{2} \mathrm{Cl}_{2}-\mathrm{FcPFu}_{2}\right]$ & 43 & 81 \\
\hline
\end{tabular}

Conditions: enyne 6 (0.20 mmol), gold(I) complex ([Au] 2 or $4 \mathrm{~mol} \%), 2 \mathrm{~mL}$ dry $\mathrm{CH}_{2} \mathrm{Cl}_{2}(0.04 \mathrm{M}$ in 6$), 20{ }^{\circ} \mathrm{C}, 3 \mathrm{~h}, \mathrm{AgSbF}_{6}(10 \mathrm{~mol} \%)$. Average yield from triplicate experiments. ${ }^{\mathrm{a}} 4 \mathrm{~mol} \%{ }^{\mathrm{b}} 50 \mathrm{~mol} \%{ }^{\mathrm{c}}$ No gold added. ${ }^{\mathrm{d}}$ Determined from ${ }^{1} \mathrm{H}$ NMR.

The salts Aul and $\mathrm{AuCl}(\mathrm{SMe})_{2}$ used as catalyst precursors in 2 mol\% amount, and cationized by using $\mathrm{AgSbF}_{6}$ (10 mol\%), achieved enyne 6 cyclization in only trace amounts (Table 1, entries 2 and 3). In the absence of gold, the use of $\mathrm{AgSbF}_{6}$ and the most efficient ligand (entries 4,5) alone, or in combination, does not achieve any reaction.

The tetrahedral cationic $\mathbf{5 e}$ and $\mathbf{5 f}$ used with or without $\mathrm{AgSbF}_{6}$ gave no cyclization reaction (entries 6,7) and remained unchanged. This remarkable stability is attributed to the very compact structure of the cationic complexes as attested by XRD analysis.
Recent works examining the reactivity of $\mathrm{Au}(\mathrm{I}) / \mathrm{Au}(\mathrm{III})$ complexes and their oxidative addition fundamental step have shown the great potential of tricoordinate trigonal $\mathrm{Au}(\mathrm{I})$ complexes using chelating ligands. ${ }^{[4 e, f, 8 c]}$ For instance, $\mathrm{Au}(\mathrm{I})$ complexes featuring diphosphino-carborane ligand achieved the oxidative addition of $\mathrm{Csp}^{2}-\mathrm{I}$ and strained $\mathrm{C}-\mathrm{C}$. However, the preference of $\mathrm{Au}(\mathrm{I})$ for two-coordinate linear geometry considerably limits ligand modulation and chelating $A u(I)$ with reduced bite angle ligands often lead to $\mathrm{Au}$...Au dinuclear structures. ${ }^{[4]]}$ Therefore, the selective formation of the trigonal $\mathbf{1 c}-\mathbf{3 c}, \mathbf{2} \mathbf{d},{ }^{[20]}$ is an excellent opportunity to further investigate their catalytic potential. Especially, because of their rarity, the stability and catalytic potential of such complexes in cyclization is still poorly unknown. The well-defined trigonal mononuclear gold iodide complex 1c was found incompetent for enyne cycloaddition (entry 8). The gold iodide complexes with electronrich phosphines $\mathbf{2 c}$ and $\mathbf{3 c}$, and chloride $\mathbf{2 d}$, gave very poor and unselective enyne conversion (entries 9-11). Clearly, their mononuclear trigonal structure does not affect favourably the course of enyne activation.

The linear digold complexes showed an effective -albeit contrasted- activity (entries 12-20) with for the electron-rich iodide $\mathbf{2 b}$ (entry 15), $88 \%$ yield cyclization of enyne 6 with $87 \%$ selectivity in 7. A still unclear positive effect of iodide compared to chloride was in general observed. A strong influence of the phosphino $\mathrm{R}$ substituent was evidenced, either lowering the

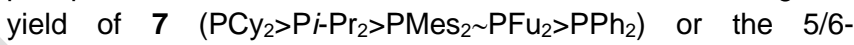
membered ring cyclization selectivity $\left(\mathrm{PCy}_{2} \sim \mathrm{PPh}_{2}>\mathrm{P} i\right.$ $\mathrm{Pr}_{2} \sim \mathrm{PMes}_{2} \sim \mathrm{PFu}_{2}$ ).

We thus used the two-coordinate linear complex $\mathbf{2} \mathbf{b}$ to extend the scope of selective intramolecular cycloaddition of different 1,6-enynes (Table 2). Similar high activity and selectivity (up to $91 \%$ ) to the endo products were obtained in presence of enynes 9-13 as observed with 6. Phenyl and 4-tertio-butylbenzene sulfonates are tolerated as protecting group for the amine (Table 2 , entries 1-3). In presence of benzyl and 4-fluorobenzyl group, furnished excellent conversion of $94 \%$ and $98 \%$ respectively with a $88 \%$ and $85 \%$ selectivity for 11 a and $12 a$ (Table 2, entries 3-4). The mesyl sulfonate product (13a) was obtained in high selectivity (91\%) in dichloroethane at $60^{\circ} \mathrm{C}$ (Table 2 , entry 5$)$.

Table 2. Scope for the intramolecular cycloaddition of different 1,6-enyne 913.

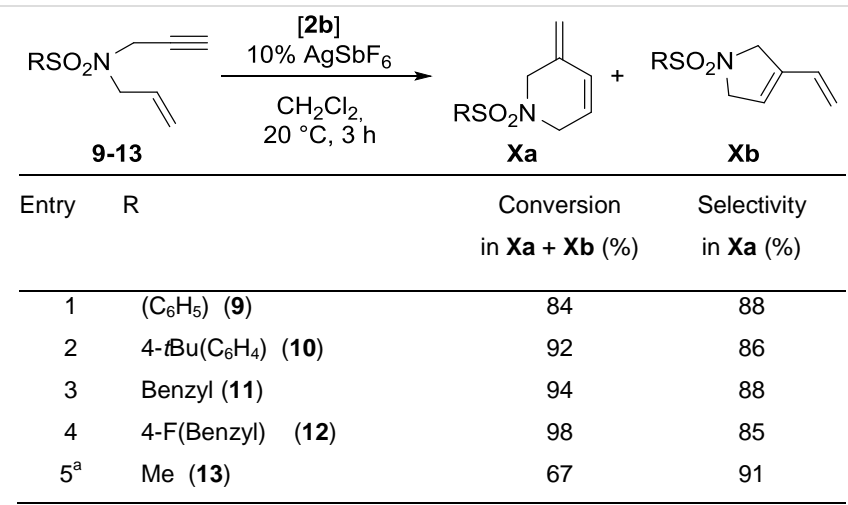


Lorsqu'un écrit scientifique issu d'une activité de recherche financée au moins pour moitié par des dotations de l'État, des collectivités territoriales ou des établissements publics, par des subventions d'agences de financement nationales ou par des fonds de l'Union européenne est publié dans un périodique paraissant au moins une fois par an, son auteur dispose, même après avoir accordé des droits exclusifs à un éditeur, du droit de mettre à disposition gratuitement dans un format ouvert, par voie numérique, sous réserve de l'accord des éventuels coauteurs, la version finale de son manuscrit acceptée pour publication, dès lors que l'éditeur met lui-même celle-ci gratuitement à disposition par voie numérique ou, à défaut, à l'expiration d'un délai courant à compter de la date de la première publication. Ce délai est au maximum de six mois pour une publication dans le domaine des sciences, de la technique et de la médecine et de douze mois dans celui des sciences humaines et sociales

Conditions: enyne 9-13 (0.20 mmol), gold(I) complex $\mathbf{2 b}(4 \mathrm{~mol} \%), 2 \mathrm{~mL}$ dry $\mathrm{CH}_{2} \mathrm{Cl}_{2}\left(0.04 \mathrm{M}\right.$ in enyne), $20^{\circ} \mathrm{C}, 3 \mathrm{~h}, \mathrm{AgSbF}_{6}(10 \mathrm{~mol} \%)$. Average yield from triplicate experiments. ${ }^{\mathrm{a}} 1,2$-dichloroethane, $60^{\circ} \mathrm{C}$.

The more challenging cycloisomerization of $\mathrm{N}$-2-methylenepropyl- $N$-propargyl-toluene-4-sulfonylamine $\mathbf{1 4}$ was also achieved in the presence of complex $\mathbf{2 b}$ (Scheme 4). The 3azabicyclo[4.1.0]hept-4-ene 14a was obtained as the major product $(51 \%)$ and isolated in $21 \%$ yield. Additionally, as secondary product the endo compound $\mathbf{1 4 b}$ was also favored in comparison to exo compound $\mathbf{1 4 c}$.

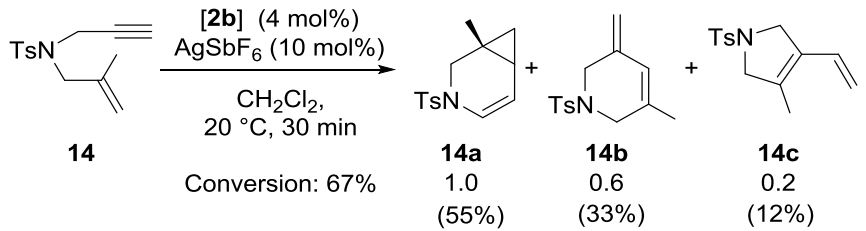

Scheme 4. Intramolecular cycloaddition of 1,6-enyne 14.

\section{Conclusion}

Tuning the electronic/steric features of phosphino groups in constrained di-tert-butylated 1,1'-bis(phosphino)ferrocenes is a reliable lever for controlling gold coordination modes in mononuclear and dinuclear $\mathrm{Au}^{\prime}$ halide complexes. We further identified that rarely reported three-coordinate and fourcoordinate mononuclear 1,1'-bis(phosphino)ferrocene $\mathrm{Au}^{\prime}$ complexes are not catalytically competent in the cycloisomerization of a challenging sulphonylamine enyne to cyclohexadiene. Conversely, digold halide bis(dicyclohexylphosphino)ferrocene $\mathbf{2 b}$ overtakes the other $\mathrm{Au}^{\prime}$ systems tested. The extension to other demanding cycloisomerization reactions furnished the endo products with high conversion and selectivity.

\section{Experimental Section}

General conditions are provided as supporting information (SI), together with details for all gold(I) complexes. The synthesis and characterization of $1 \mathbf{a}$ is illustrated for example below. Details on the existence of gold complexes conformers and complexes fluxionality (VT-NMR) as well as $\mathrm{NCl}$ computation, are also provided as SI. XRD details are available in $\mathrm{SI}$ for compounds with CCDC numbers: $1983785\left(\mathbf{1 a}-\mathrm{CH}_{2} \mathrm{Cl}_{2}\right), 1983786$ (1a$\mathrm{CH}_{3} \mathrm{OH}$ ), 1983787 (1c), 1983788 (2a), 1983789 (2b), 1983790 (2c), 1983791 (2d), 1983792 (3a), 1983793 (3b), 1983794 (3c), 1983795 (4a$\left.\mathbf{C}_{6} \mathbf{H}_{12}\right), 1983796$ (4a), 1983797 (4b) 1983798 (5e).

General procedure for the synthesis of dinuclear gold(I) complexes of ferrocenyl diphosphines. A $50 \mathrm{ml}$ round flask equipped with a magnetic stirring bar was charged with ferrocenyl diphosphines (1 equiv) and gold precursor [AuCl( $\left.\left.\mathrm{SMe}_{2}\right)\right]$ or Aul (2 equiv) degassed before addition of dichloromethane. The solution was stirred at room temperature for $5 \mathrm{~min}$, and the mixture was filtrated on Celite ${ }^{\circledR}$ and rinsed with dichloromethane. The solvent was removed in vacuum to give the corresponding gold complex, which was further purified by solvation in dichloromethane followed by a precipitation after slow addition of pentane. The synthesis of ferrocenyl diphosphines was achieved according literature reports. ${ }^{[17]}$

[1,1'-Bis(diphenylphosphino)-3,3'-di(tert-butyl)ferrocene] digold(I) dichloride (1a). The complexation of rac-1 $(33 \mathrm{mg}, 0.05 \mathrm{mmol})$ and [AuCl(SMe $)$ ] $(29 \mathrm{mg}, 0.10 \mathrm{mmol})$ affords $1 \mathrm{a}$ in $99 \%$ (56 mg) yield after precipitation from $\mathrm{CH}_{2} \mathrm{Cl}_{2}$ by addition of pentane. Two conformers coexisting in solution. ${ }^{1} \mathrm{H}$ NMR $\left(500 \mathrm{MHz}, \mathrm{CD}_{2} \mathrm{Cl}_{2}\right), \delta(\mathrm{ppm})=8.19$ (bs, $2 \mathrm{H}, \mathrm{Ph}), 7.54-7.27(\mathrm{~m}, 18 \mathrm{H}, \mathrm{Ph}), 4.78$ (bs, $1 \mathrm{H}, H \mathrm{Cp}), 4.51$ (s, 3H, HCp), 4.24 (bs, $1 \mathrm{H}, H \mathrm{Cp}$ ), 3.69 (bs, $1 \mathrm{H}, H \mathrm{Cp}$ ), 1.24 (bs, $9 \mathrm{H}, t-\mathrm{Bu}$ ), 0.84 (bs, $9 \mathrm{H}$, $t$-Bu). ${ }^{31} \mathrm{P}\left\{{ }^{1} \mathrm{H}\right\}$ NMR $\left(202.5 \mathrm{MHz}, \mathrm{CD}_{2} \mathrm{Cl}_{2}\right): \delta(\mathrm{ppm})=27.9$ (bs, $\left.42 \%\right), 24.2$ (58\%) (bs, 2P). ${ }^{13} \mathrm{C}\{1 \mathrm{H}\} \mathrm{NMR}\left(125 \mathrm{MHz}, \mathrm{CD}_{2} \mathrm{Cl}_{2}\right): \delta(\mathrm{ppm})=135.7(\mathrm{CPh})$, 134.4 (CPh), $133.7(C P h), 132.7(C P h), 131.5(C P h), 129.9\left(\mathrm{~d}, \mathrm{~J}_{\mathrm{CP}}=14\right.$ $\mathrm{Hz}, C \mathrm{CPh}), 129.4$ (CPh), 111.6 (CCp), 108.2 (CCp), 74.4 (CCp), 73.3 (CCp), 73.0 (CCp), 70.6 (CCp), $32.5[C(t-\mathrm{Bu})], 31.0 \quad\left[\mathrm{CH}_{3}(t-\mathrm{Bu})\right]$ Elemental analysis: Calcd (\%) for $\mathrm{C}_{42} \mathrm{H}_{44} \mathrm{Au}_{2} \mathrm{Cl}_{2} \mathrm{FeP}_{2} \cdot 1 \mathrm{CH}_{2} \mathrm{Cl}_{2}$ : C $42.46, \mathrm{H}$ 3.81. Found: C 42.53, H 3.86. HRMS + p ESI (m/z) [M-Cl] Calcd for $\mathrm{C}_{42} \mathrm{H}_{44} \mathrm{Au}_{2} \mathrm{ClFeP}_{2}: 1095.128737$. Found: $\mathrm{m} / \mathrm{z}=1095.12793$.

Electrochemistry reagents and instrumentation. Tetra- $n$ butylammonium hexafluorophosphate $\left(\mathrm{TBAPF}_{6}\right)$ was synthesized by mixing stoichiometric amounts of tetra- $n$-butylammonium hydroxide (AlfaAesar, $40 \% \mathrm{w} / \mathrm{w}$ aq. sol.) and hexafluorophosphoric acid (Alfa-Aesar, ca $60 \% \mathrm{w} / \mathrm{w}$ aq. sol.). The supporting electrolyte (tetraethylammonium tetrafluoroborate) was degassed under vacuum before use and then dissolved to a concentration of $0.1 \mathrm{M}$. Voltammetry analyses were carried out in a standard three-electrode cell, with an Autolab PGSTAT 302N potentiostat, connected to an interfaced computer that employed Electrochemistry Nova software. The reference electrode was a $\mathrm{KCl}$ saturated calomel electrode (SCE) separated from the analyzed solution by a sintered glass disk filled with the background solution. The auxiliary electrode was a platinum wire separated from the analyzed solution by a sintered glass disk filled with the background solution. The working electrode was a platinum electrode disk, operating in $\mathrm{CH}_{2} \mathrm{Cl}_{2}(0.1 \mathrm{M}$ TBAPF $_{6}$ ), with potential for ferrocene ${ }^{(+/ 0)}$ couple $+0.38 \mathrm{~V}$ vs. SCE.

General procedure for the cycloisomerization of enynes 6-14. Enyne 6-14 $(0.20 \mathrm{mmol}, 50 \mathrm{mg})$ and silver(l) salt $\mathrm{AgSbF}_{6}$ (0.1 equiv) were mixed in dry $\mathrm{CH}_{2} \mathrm{Cl}_{2}(2 \mathrm{~mL})$ and were added to a solution of gold(I) complexes (2 mol\%) in dry $\mathrm{CH}_{2} \mathrm{Cl}_{2}(1 \mathrm{~mL})$. The mixture was stirred at room temperature $\left(20^{\circ} \mathrm{C}\right)$ for $3 \mathrm{~h}$. The mixture was then filtered through $\mathrm{SiO}_{2}$. The solvent was evaporated under reduced pressure to give the crude product. The conversion was determinated by ${ }^{1} \mathrm{H}$ NMR according spectrum given for endo and exo according the literature. Compound endo was isolated by using flash chromatography (heptane/ethyl acetate, $90 / 10$ ). Due to the low yields obtained in general during the reactions exo was not isolated $(<15 \%)$.

\section{Acknowledgements}

This work was supported by the ANR program (ANR-16-CE070007-02, Icare_1, grant for H. N.), by the CNRS, the Université de Bourgogne, the Conseil Régional BFC (CHIMENE project, PhD grant for T.-A. N.), the PIA-excellence ISITE-BFC program (COMICS project) and the FEDER which are all sincerely acknowledged.

Keywords: Functionalized ferrocenes • digold complexes • halides $\bullet$ trigonal gold $(\mathrm{I}) \cdot$ enyne cyclization

[1] a) E. Jimenez-Nunez, A. M. Echavarren, Chem. Rev. 2008, 108, 3326; b) Z. Li, C. Brouwer, C. He, Chem. Rev. 2008, 108, 3239; c) A. S. K. Hashmi, M. Rudolph, Chem. Soc. Rev. 2008, 37, 1766; d) A. Corma, A. Leyva-Perez, M. J. 
Lorsqu'un écrit scientifique issu d'une activité de recherche financée au moins pour moitié par des dotations de l'État, des collectivités territoriales ou des établissements publics, par des subventions d'agences de financement nationales ou par des fonds de l'Union européenne est publié dans un périodique paraissant au moins une fois par an, son auteur dispose, même après avoir accordé des droits exclusifs à un éditeur, du droit de mettre à disposition gratuitement dans un format ouvert, par voie numérique, sous réserve de l'accord des éventuels coauteurs, la version finale de son manuscrit acceptée pour publication, dès lors que l'éditeur met lui-même celle-ci gratuitement à disposition par voie numérique ou, à défaut, à l'expiration d'un délai courant à compter de la date de la première publication. Ce délai est au maximum de six mois pour une publication dans le domaine des sciences, de la technique et de la médecine et de douze mois dans celui des sciences humaines et sociales

Sabater, Chem. Rev. 2011, 111, 1657; e) C. Nieto-Oberhuber, M. Paz Munoz, S. Lopez, E. Jimenez-Nunez, C. Nevado, E. Herrero-Gomez, M. Raducan, A. M. Echavarren, Chem. Eur. J. 2006, 12, 1677.

[2] a) A. Arcadi, Chem. Rev. 2008, 108, 3266; b) A. Fürstner, Chem. Soc. Rev. 2009, 38, 3208; c) M. Rudolph, A. S. K. Hashmi, Chem. Soc. Rev. 2012, 41, 2448; d) C. Obradors, A. Echavarren, Chem. Commun. 2014, 16.

[3] a) X. Zhao, M. Rudolph, A. S. K. Hashmi, Chem. Commun. 2019, 55, 12127; b) A. Leyva-Pérez, A. Doménech-Carbó, A. Corma, Nature Commun 2015, 6, 6703 .

[4] a) D. J. Gorin, B. D. Sherry, F. D. Toste, Chem. Rev. 2008, 108, 3351; b) R Widenhoefer, Chem.-Eur. J. 2008, 14, 5382; c) E. Tkatchouk, N. P. Mankad, D. Benitez, W. A. Goddard, III, F. D. Toste, J. Am. Chem. Soc. 2011, 133, 14293; d) Y. Wang, Z. Wang, Y. Li, G. Wu, Z. Cao, L. Zhang, Nature Commun 2015, 5, 4470; e) M. Joost, A. Amgoune, D. Bourissou, Angew. Chem., Int. Ed. 2015, 54, 15022; f) A. Zeineddine, L. Estevez, S. Mallet-Ladeira, K. Miqueu, A. Amgoune, D. Bourissou, Nature Commun. 2017, 8, 1; g) N. Dwadnia, J. Roger, N. Pirio, H. Cattey, R. Ben Salem,J.-C. Hierso, Chem.- Asian J., 2017, 12, 459.

[5] C. Garcia-Morales, B. Ranieri, I. Escofet, C. Obradors, A. I. Konovalov, A. M. Echavarren, J. Am. Chem. Soc. 2017, 139, 13628. A ferrocenyl diphosphino gold(I) complexes with no aurophilic interactions is reported. [6] a) V. Vreeken, D. L. J. Broere, A. C. H. Jans, M. Lankelma, J. N. H. Reek, M. A. Siegler, J. I. van der Vlugt, Angew. Chem., Int. Ed. 2016, 55, 10042; b) M. Lankelma, V. Vreeken, M. A. Siegler, J. I. van der Vlugt, Inorganics, 2019, 7, 28.

[7] C.-M. Che, S.-W. Lai, Coord. Chem. Rev. 2005, 249, 1296.

[8] The formation of mononuclear three-coordinate $\mathrm{Au}^{\prime}$ complexes using diphosphines is strongly competed by the formation of dinuclear complexes [LAu(...)AuL], see: a) M. Osawa, M.-A. Aino, T. Nagakura, M. Hoshino, Y. Tanaka, M. Akita, Dalton Trans., 2018, 47, 8229; b) M. Viotte, B. Gautheron, M. M. Kubicki, Y. Mugnier, R. V. Parish, Inorg. Chem. 1995, 34, 3465; c) For a recent carbene-stabilized trigonal planar $\mathrm{Au}(\mathrm{l})$ complex with a strongly hindering carboranyl-supported diphosphine, see: A. Zeineddine, F. Rekhroukh, E. D. Sosa Carrizo, S. Mallet-Ladeira, K. Miqueu, A. Amgoune, D. Bourissou, Angew. Chem., Int. Ed. 2018, 57, 1306.

[9] Four-coordinate tetrahedral gold(I) complexes synthesized from monophosphine ligands and applications: a) P. G. Jones, J. Chem. Soc., Chem. Commun. 1980, 1031; b) R. C. Elder, E. H. Kelle Zeiher, M. Onady, R. R. Whittle, J. Chem. Soc., Chem. Commun. 1981, 900; c) P. G. Jones, G. M. Sheldrick, J. A. Muir, M. M. Muir, L. B. Pulgar, J. Chem. Soc., Dalton Trans. 1982, 2123; d) J. M. Forward, Z. Assefa, R. J. Staples, J. P. Fackler, Jr, Inorg. Chem. 1996, 35, 16.

[10] Four-coordinate tetrahedral gold(I) complexes synthesized from chelating diphosphine (or arsine) ligands and applications: a) V. W.-W. Yam, C.-L. Chan S. W.-K. Choi, K. M.-C. Wong, E. C.-C. Cheng, S.-C. Yu, P.-K. ng, W.-K. Chan, K.-K. Cheung, Chem. Commun. 2000, 53 and references therein; b) A. Kaeser, O. Moudam, G. Accorsi, I. Séguy, J. Navarro, A. Belbakra, C. Duhayon, N. Armaroli, B. Delavaux-Nicot, J.-F. Nierengarten, Eur. J. Inorg. Chem. 2014, 1345; c) For a rare tetracoordinated digold complex, see: S. A. Bhat, J. T. Mague, M. S. Balakhrishna, Dalton Trans., 2015, 47, 17697; d) E. K. Dennis, J. H. Kim, S. Parkin, S. G. Awuah, S. Garneau-Tsodikova, J. Med. Chem. 2020, 63, 2455.

[11] A. Gómez-Suárez, S. Nolan, Angew. Chem., Int. Ed. 2012, 51, 8156.

[12] D. T. Hill, G. R. Girard, F. L. McCabe, R. K. Johnson, P. D. Stupik, J. H. Zhang, W. M. Reiff, D. S. Eggleston, Inorg. Chem. 1989, 28, 529.

[13] a) M. C. Gimeno, A. Laguna, C. Sarroca, P. G. Jones, Inorg. Chem. 1993, 32, 5926; b) F. Canales, M. C. Gimeno, P. G. Jones, A. Laguna, C. Sarroca, Inorg. Chem. 1997, 36, 5206.

[14] a) A. Houlton, D. M. P. Mingos, D. M. Murphy, D. J. Williams, L.-T. Phang, L. S. A. Hor, J. Chem. Soc., Dalton Trans. 1993, 3629. b) P. Lai-Tee, T. S. A. Hor, Z. Zhong-Yuan, T. C. W. Mak, J. Organomet. Chem. 1994, 469, 253.

[15] A. Houlton, R. M. G. Roberts, J. Silver, R. V. Parish, J. Organomet. Chem. 1991, 418, 269.

[16] V. Rampazzi, J. Roger, R. Amardeil, M.-J. Penouilh, P. Richard, J.-C. Hierso, Inorg. Chem. 2016, 55, 10907.
[17] Diastereoselective pure rac synthesis is achieved and used herein, see for deails: J. Roger, S. Royer, H. Cattey, A. Savateev, R. V. Smaliy, A. N. Kostyuk, J.-C. Hierso, Eur. J. Inorg. Chem. 2017, 330.

[18] a) S. F. Hartlaub, N. K. Lauricella, C. N. Ryczek, A. G. Furneaux, J. D. Melton, N. A. Piro, W. S. Kassel, C. Nataro, Eur. J. Inorg. Chem., 2017, 2017, 424; S. L. Kahn, M. K. Breheney, S. L. Martinak, S. M. Fosbenner, A. R. Seibert, W. S. Kassel, W. G. Dougherty, C. Nataro, Organometallics, 2009, 28, 2119.

[19] A more detailed investigation is needed to fully understand these CV signatures, we envisioned an intramolecular electron transfer $\left(\mathrm{Fe}^{\mathrm{III} / \mathrm{Fe}} \mathrm{II}\right) /\left(\left[/ 1 / 2 \mathrm{l}_{2}\right)\right.$. [20] Only one $\mathrm{Au}^{\prime} \mathrm{Cl}$ complex of this c1 type was reported, obtained with the concomitant formation of its gold dinuclear analogue $(25 \%)$, see ref. $8 \mathrm{~b}$.

[21] In ref. 1e the other substituted sulphonamide 1,6-enynes employed gave conversions $>84 \%$ in 5 to 30 min, evidencing 6 as a particularly challenging substrate. In general selectivity dropped upon longer reaction time. 


\section{Table of Contents}

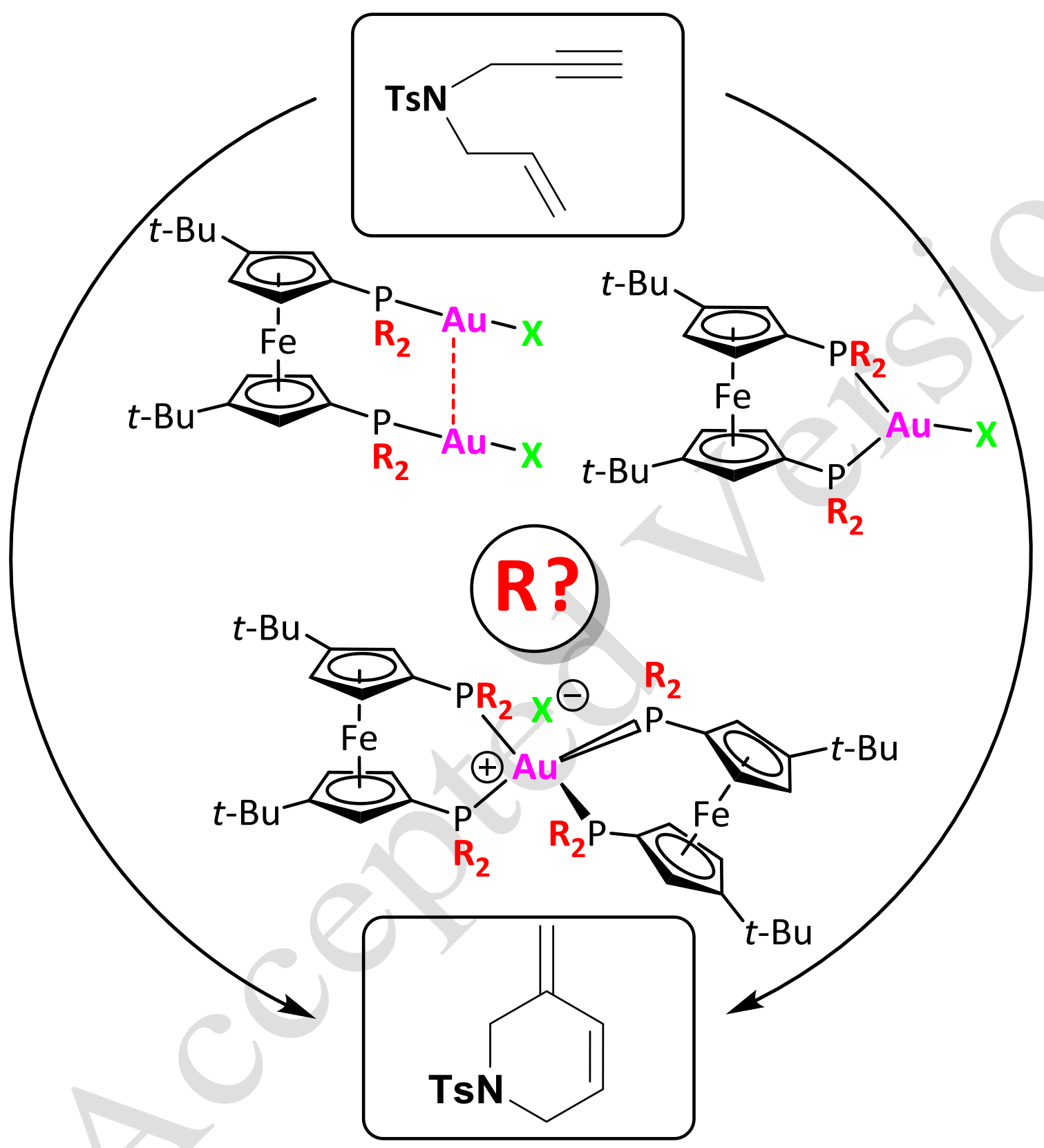

Linear, trigonal and tetrahedral gold $(\mathrm{I})$ complexes are selectively formed depending on the $\mathrm{R}$ phosphino groups on ferrocenyldiphosphines: linear digold(I) achieved cycloisomerization of enyne-sulphonamides into cyclohexadienes. 